\title{
Effect of Squid (Sepiotheutis lessoniana) Ink on Hematological Profile of Rats Rattus norvegicus
}

\author{
Delianis Pringgenies ${ }^{{ }^{*}}$, Meida M. M. Pertiwi $^{1}$ and Ali Ridlo ${ }^{1}$ \\ ${ }^{1}$ Department of Marine Sciences, Faculty of Fisheries and Marine Sciences, Diponegoro University, \\ Semarang, Indonesia.
}

Authors' contributions

This work was carried out in collaboration among all authors. Author DP designed the study and research idea, wrote the first draft of the manuscript. Author MMMP performed the research and author AR supervising research method. All authors read and approved the final manuscript.

Article Information

DOI: $10.9734 / A R R B / 2020 / v 35 i 130179$ Editor(s):

(1) Md. Aminur Rahman, Jashore University of Science and Technology, Bangladesh. Reviewers:

(1) Arthur N. Chuemere, University of Port Harcourt, Nigeria. (2) Mohamed El. Sayed Megahed, National Institute of Oceanography and Fisheries, Egypt. Complete Peer review History: http://www.sdiarticle4.com/review-history/55320

Original Research Article

Received 04 January 2020

Accepted 12 March 2020

Published 16 March 2020

\section{ABSTRACT}

Iron deficiency anaemia includes the highest incidence of nutritional deficiency diseases in the world. Red cell indices on full blood counts is regularly used to diagnose early anaemia. Currently strategies medicines of iron deficiency anaemia are belonged to preventif medicine as well as fortification of food and iron supplementation directly to the body. Recent studies show the effectiveness of treatment of iron deficiency anaemia in rats with squid ink. This study aim is to analyse the iron content of squid ink (Sepioteuthis lessoniana) and squid ink effects on haematological profile of male Wistar rat Rattus norvegicus. The measured iron content of squid ink (Sepioteuthis lessoniana) is $2,14 \pm 0,46 \mathrm{mg} / \mathrm{g}$. Rats were used in this study, are induced $\mathrm{NaNO}_{2}(50$ $\mathrm{mg} / \mathrm{kgbw}$ ( $1 \mathrm{ml}$ dosing volume)) at first, then divided into 4 groups experiment for 14 days experimental. The $1^{\text {st }}$ group is negative control (without any treatment), $2^{\text {nd }}$ group is positive control (with Sangobion $^{\circledR}$ ), $3^{\text {rd }}$ group is given a low dosage of squid ink $(10 \mathrm{mg} / \mathrm{kgbw} / \mathrm{day})$ and the last $4^{\text {th }}$ group is given a high dosage of squid ink $(100 \mathrm{mg} / \mathrm{kgbw} / \mathrm{day})$. Based on the result, there was an effect of given squid ink to the haemoglobin, hematocrit, mean corpuscular volume, mean corpuscular haemoglobin concentration, mean haemoglobin content, red blood cell distribution width and red blood cell count of rats that showed by increasing numbers to the end of the 
experiment compared to the negative control $\left(1^{\text {st }}\right.$ group). The most significant effect is in haemoglobin, especially $\mathrm{Hb}$ of rats which appeared on the low dosage of squid ink group and positive control group to the negatif group $(p<0,05)$.

Keywords: Fe; Hct; Hb; red blood cell; MCV; MCHC; RDW-CV; squid ink; S. lessoniana.

\section{INTRODUCTION}

Anaemia is a public health issue with a detrimental effect on the mortality rate of mother and child. The population which are at risk the most from anaemia are children aged 0-5 years old, women during fertility and pregnant women [1]. Iron deficiency has been attributed as the cause if anemia, yet this condition is among the most prevalent health issue all around the world [2]. Malnutrition can lower resistance to infection, exacerbate inflammation and increase the risk of anemia. A balanced diet complemented by mineral and vitamin supplements, especially those with antioxidant properties, is necessary for the hemopoietic functions of tissues and in the production of erythropoietin to regulate the formation of red blood cells [3]. Several iron-rich compounds has been applied in a preventive solution to the issue of iron deficiency. Among them are iron sulfate with its high levels iron content and good absorption rate up to a certain level, which can help alleviate symptoms of iron deficiency and anaemia. However supplement containing this compound can also cause undesirable side-effects including diarrhoea, discomfort, constipation and epigastric tenderness [4]. Diagnosis for anaemia is made after sharp decrease in red blood cells count is confirmed, indicated such by lab tests such as complete blood count test. However, it is considerably more difficult to diagnose iron deficiency, which may involve several status indicators for iron in the process. First, red blood cell index determined in the complete blood count test can indicate mean haemoglobin cell value. Haemoglobin and mean corpuscular volume (MCV) tests are affordable, readily available and sensitive procedures. However, these tests will show abnormal results in people with chronic iron deficiency and in cases where the person tested has been suffering from certain chronic illnesses, including hemoglobinopathy (such as thalassemia) or sideroblastic anemia. Results of MCV may be used integrated into indicators which determine nutritional deficiency [1].

A recent study found that the supplementation of squid ink on rats can reduce the risk of anaemia due to iron deficiency, which is attributed to the high bioavailability of iron in squid ink [2]. Therefore, this research aims to determine the content of iron in squid ink and the impact of squid ink dietary supplement on the haematological profile of Rattus norvegicus.

\section{MATERIALS AND METHODS}

\subsection{Preparing the Squid Ink}

The ink used in this study was collected from the species Sepiotheutis lessoniana. Fresh specimens were obtained from Fish Auction of Tambak Lorok Market, Semarang. Samples were laid in ventral position before being dissected. Afterwards, the ink duct was separated from the rest of the digestive organs using a pair of sterilized tweezers. The ink sac was then extracted from the body of the squid, and the ink duct was cut using a pair of sterilized scissors [5]. The ink from all the extracted sacs was collected inside a brown, sterilized vial, after which it was stored in a freezer in $-20^{\circ} \mathrm{C}$ of temperature. The squid ink preparation was made by putting $20 \mathrm{ml}$ of stored ink into a $1 \mathrm{~L}$ beaker glass, and then $100 \mathrm{ml}$ of distilled water and $1.2 \%$ commercial vinegar acid was added to a volume of $1 \mathrm{~L}$. The solution was stored for 24 hours. After storage, the solution was coagulated using a rotary evaporator into dry, paste-like lumps. The content of iron per milligram of the preparation was determined using Atomic Absorption Spectrophotometry (AAS) at 248.3 $\mathrm{nm}$ of wavelength.

\subsection{In vivo Test of Squid Ink}

The dry paste squid ink was introduced into 24 male rat subjects, all of which were made anaemic buy the induction of $\mathrm{NaNO}_{2}$ at $50 \mathrm{mg} / \mathrm{kg}$ of body weight [6]. The subjects were grouped into four treatment groups, as presented in Fig. 1. The same diet was administered across the treatment groups ad libitum, and each group were given different treatment for 14 consecutive days. The dose of Sangobion ${ }^{\circledR}$ used for the positive control group was $4.5 \mathrm{mg} / \mathrm{kg}$ of body weight. The description of each control group is presented in Fig. 1. 


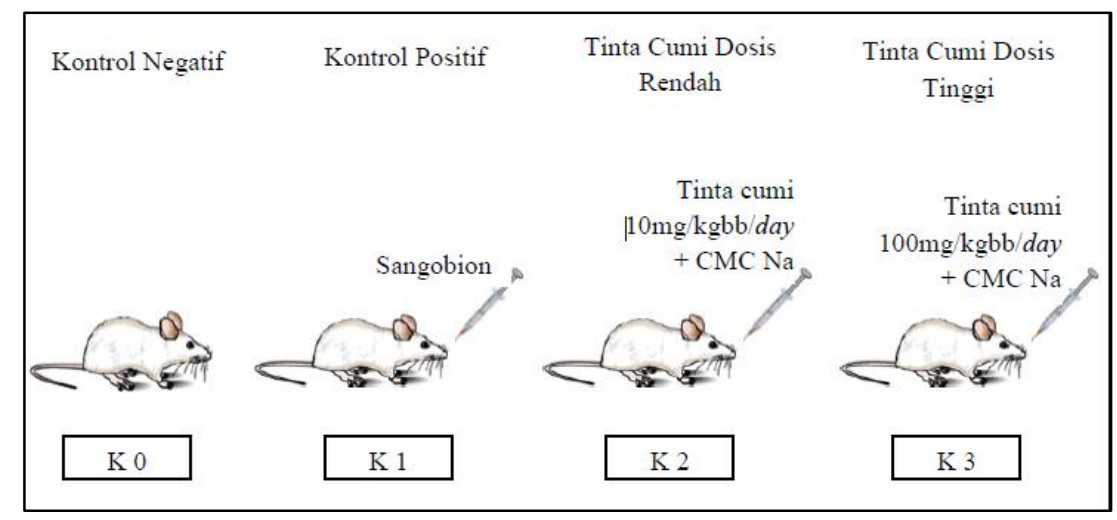

Fig. 1. Treatment scheme on each subject group

\subsection{Complete Blood Count Test and Data Analysis}

After the treatment period ended, the blood sample from all subjects was extracted from vein on the eye using capillary tubes. The blood sampling was performed twice on each subject, once after the induction of $\mathrm{NaNO}_{2}$ compound prior to intervention and one more time after the treatment period had expired to determine any change in the blood. The complete blood count test was performed using an Automated Hematology Analyzer device. This test can determine $\mathrm{Hb}$ count, Red Blood Cells count, $\mathrm{MCV}, \mathrm{MCH}, \mathrm{MCHC}$ and RDW-CV. The data obtained were then statistically analyzed using one-way analysis of variance (ANOVA) which was ran on SPSS 17.0 for Windows.

\section{RESULTS AND DISCUSSION}

AAS at $248.3 \mathrm{~nm}$ of wavelength determined that the ink of Sepioteuthis lessoniana contained 2.14 $\pm 0.46 \mathrm{mg} / \mathrm{g}$ of iron. The existence of iron in squid ink is attributed to its eumelanin, which has a very positive affinity to capture ferrite ion (DiMauro et al. 2017). Acetic acid was used as a solvent in this research to create an acidic environment. The necessity of having an acidic environment was due to the fact that the extracted salt (containing iron) is soluble in acid, whereas a base solution would result in the hydrolysis of metallic contents into suspension, making measurements of iron content in the final result difficult to determine. Acetic acid or vinegar was used as a solvent in the extraction process because it is acidic, non-volatile, non-corrosive and non-toxic in nature [7].

Post-intervention blood analysis determined that the highest mean of hemoglobin count was found in low dose squid ink treatment, at $15.150 \pm$ $0.550 \mathrm{~g} / \mathrm{dL}$. This result was followed by a positive control group at $14.833 \pm 0.446 \mathrm{~g} / \mathrm{dL}$, high dose squid ink treatment group at $14.433 \pm 0.807 \mathrm{~g} / \mathrm{dL}$. The lowest mean haemoglobin count was found in the negative control group at $12.417 \pm 1.599$ $\mathrm{g} / \mathrm{dL}$. A pattern of condition improvement after the intervention was observed among the treatment groups and positive control groups, whereas the negative control group showed no betterment in condition after the intervention period had expired.

Post intervention blood analysis determined that the highest mean of hematocrit was found in low dose squid ink treatment, at $43.8 \pm 1.202 \%$. This result was followed by a positive control group at $42.55 \pm 1.555 \%$, high dose squid ink treatment group at $41.317 \pm 3.312 \%$. The lowest mean haemoglobin count was found in the negative control group at $37.933 \pm 7.053 \mathrm{~g} / \mathrm{dL}$. A pattern of condition improvement after the intervention was observed among the treatment groups and positive control groups, albeit with almost negligible gain. The negative control did not show improvement in condition.

The highest mean RBC after 14 days of the treatment period was found in low dose squid ink treatment at $8.158 \pm 0.362\left(10^{6} / \mathrm{\mu l}\right)$, followed by the positive control group at $8.028 \pm 0.342\left(10^{6} / \mu \mathrm{l}\right)$ and high dose squid ink treatment group at $7.782 \pm 0.757\left(10^{6} / \mu \mathrm{l}\right)$. The lowest mean RBC was found in the negative control group at $7.607 \pm 0.616\left(10^{6} / \mu \mathrm{l}\right)$. The trend which loss of RBC occurring with high dose squid ink treatment group was considered high, even when compared to that of the negative control group. However, the mean value across all treatment group and positive control were still higher than that of the negative control group. Several 


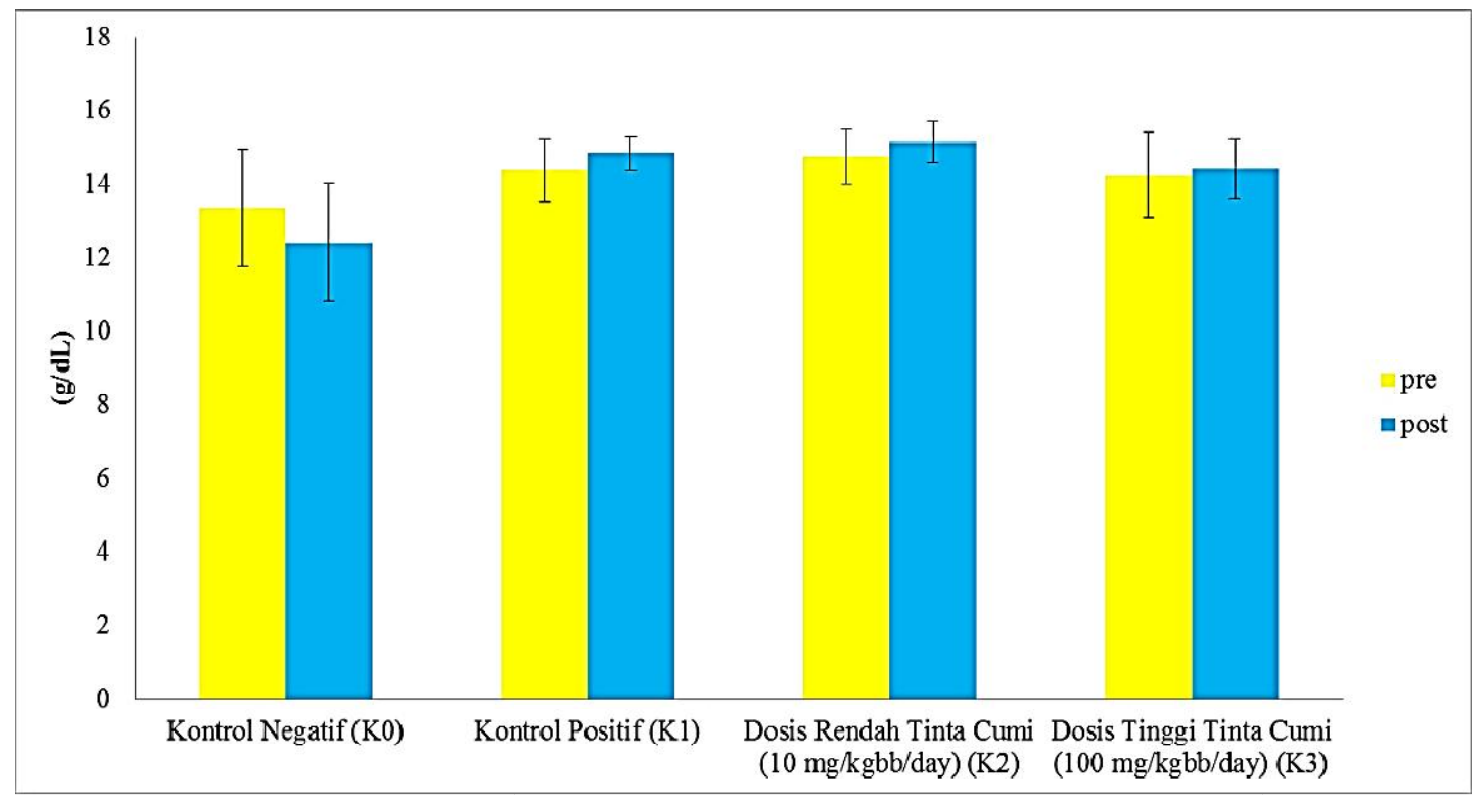

Fig. 2. MHV pattern diagram before and after treatment

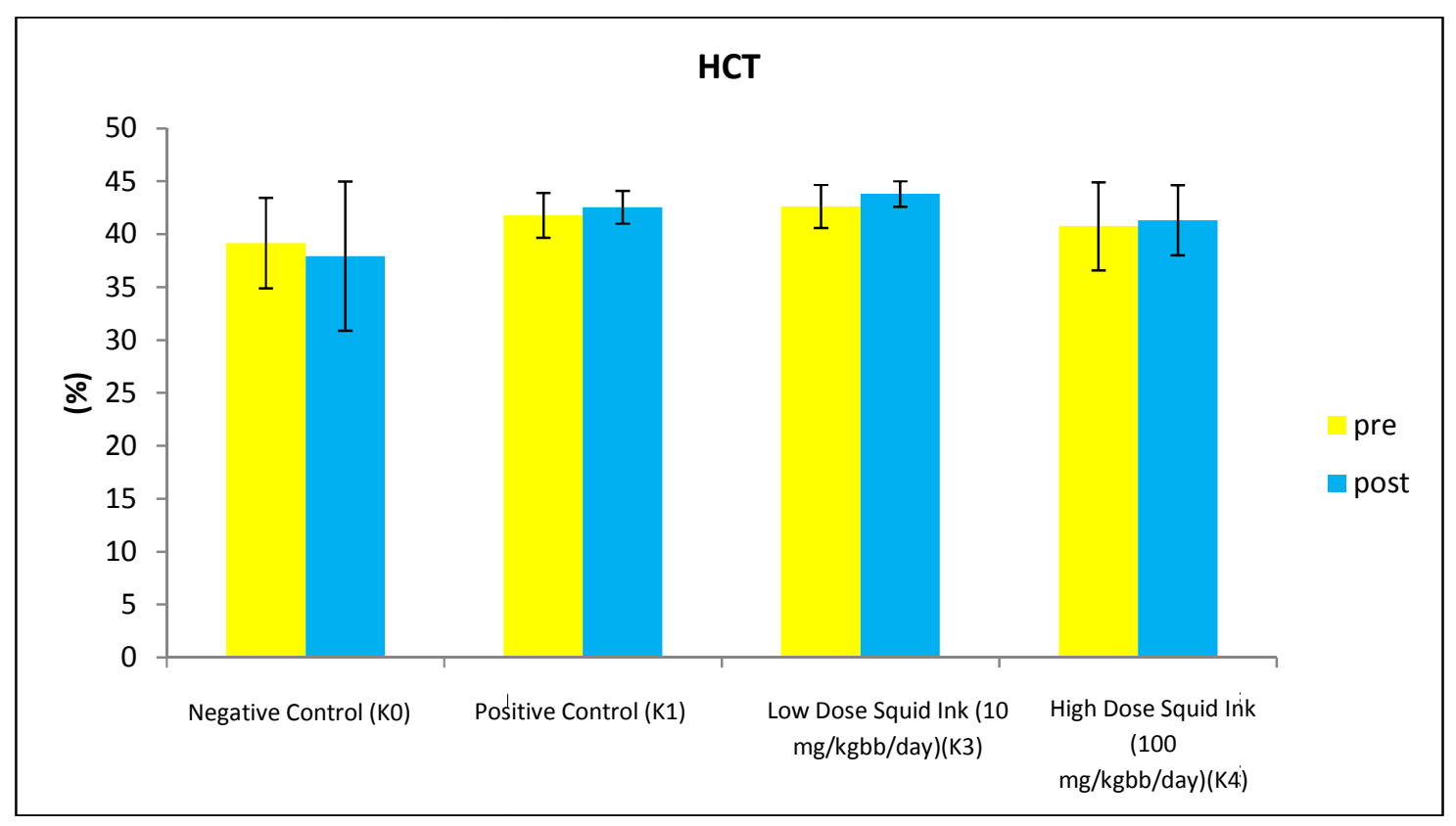

Fig. 3. MHC pattern diagram before and after treatment

pattern indicated gain from the condition observed prior to the treatment, albeit very slightly, except for the values observed in subjects from negative control group and high dose squid ink treatment group.

The highest mean MCV after 14 days of the treatment period was found in low dose squid ink treatment at $53.733 \pm 1.758 \mathrm{fL}$, followed by the high dose squid ink treatment group at $53.2 \pm 2.231 \mathrm{fL}$ and positive control group at $53.05 \pm 2.381 \mathrm{fL}$. The lowest mean MCV was found in the negative control group at $50.383 \pm 11.62 \mathrm{fL}$. A pattern of condition improvement after the intervention was observed among the treatment groups and positive control 


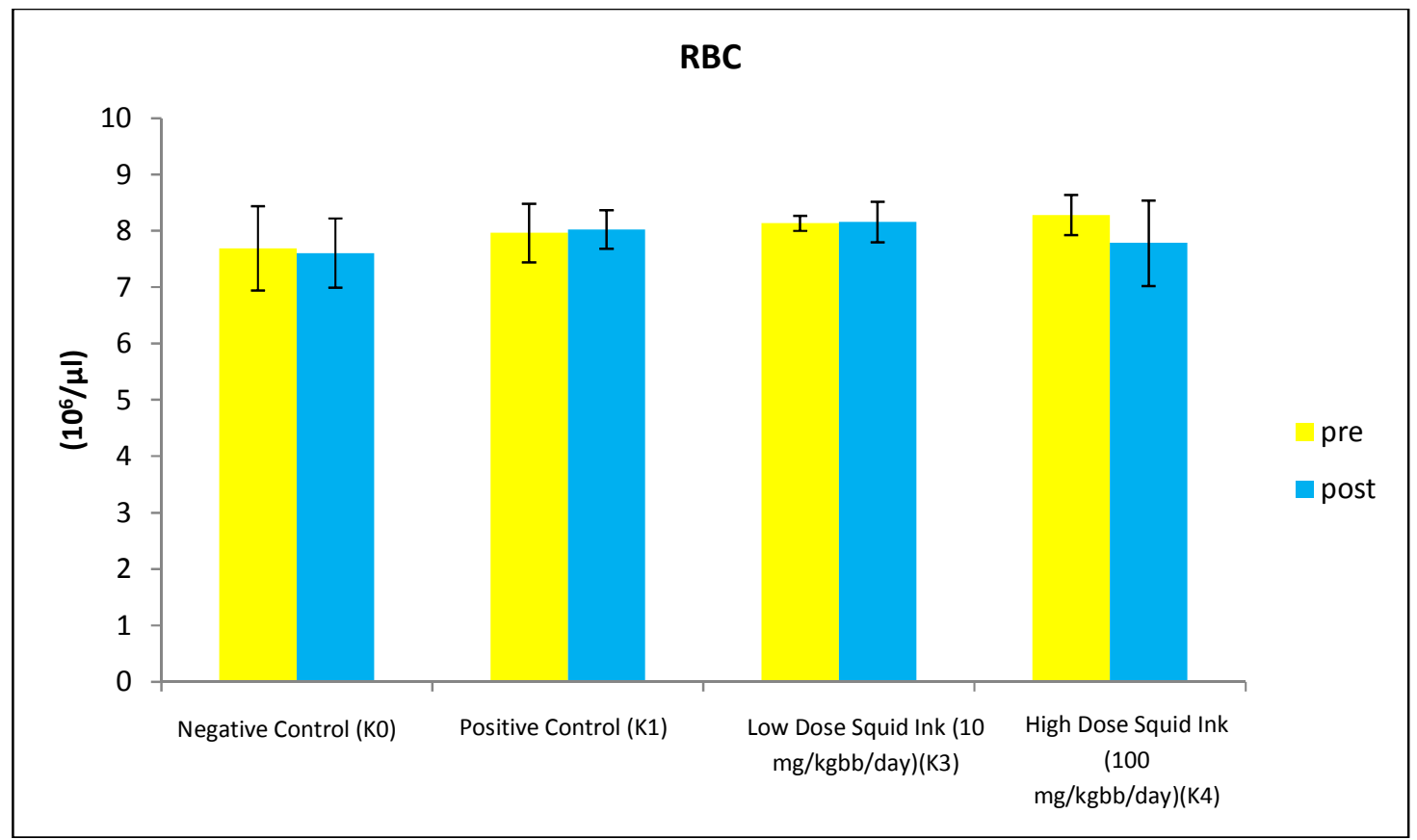

Fig. 4. Mean RBC pattern diagram before and after treatment

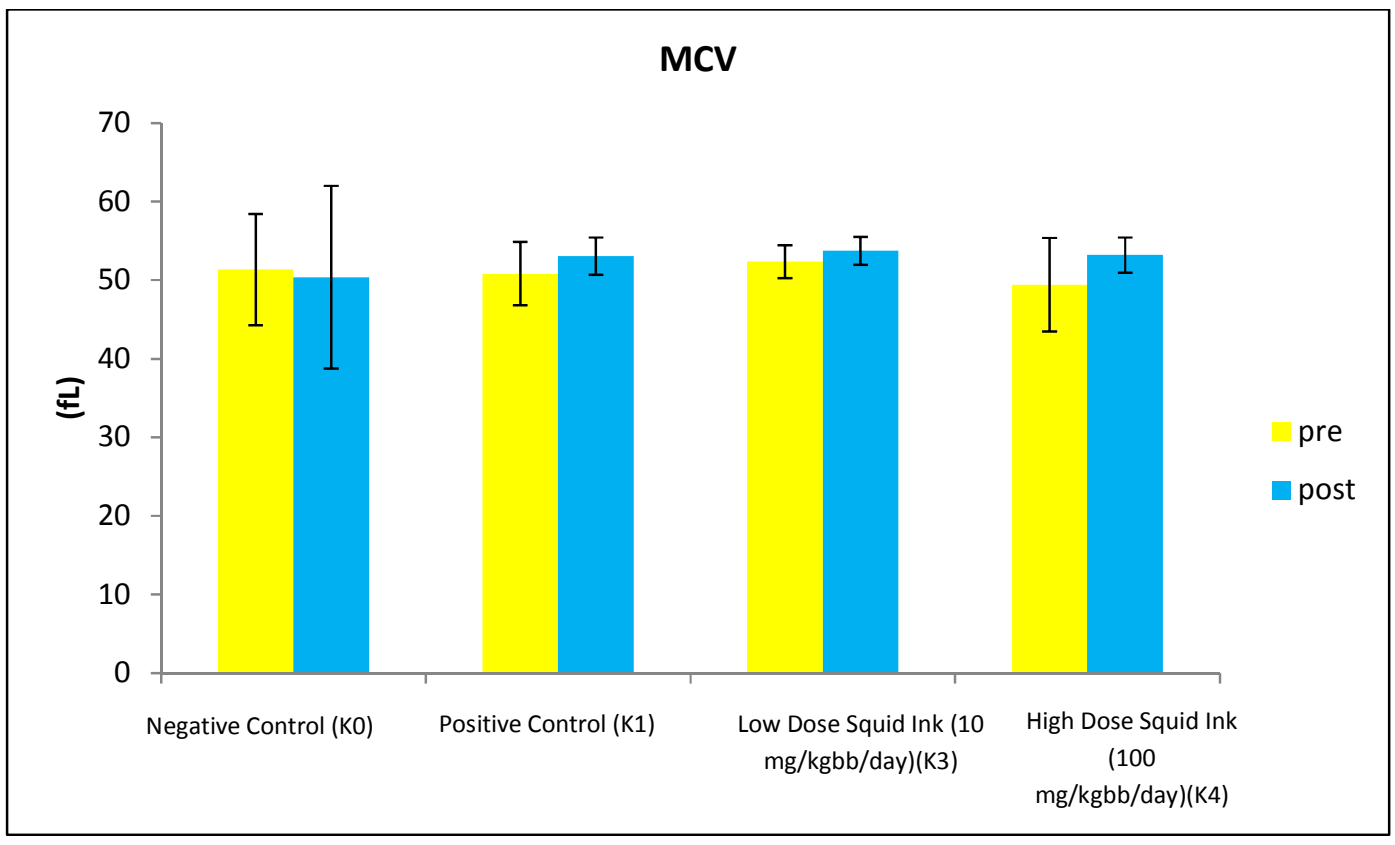

Fig. 5. MCV pattern diagram before and after treatment

groups, albeit with almost negligible gain. The negative control did not show improvement in condition.

The highest $\mathrm{MCH}$ count was found in the low dose squid ink treatment at $18.583 \pm 0.387 \mathrm{\rho g}$.
This result was followed by a positive control group at $18.483 \pm 0.755 \rho g$, high dose squid ink treatment group at $18.35 \pm 0.675 \rho \mathrm{gg}$. The lowest mean haemoglobin count was found in the negative control group at $16.400 \pm 2.356 \rho g$. A pattern of condition improvement after the 
intervention was observed among the treatment groups and positive control groups, albeit with almost negligible gain. The negative control did not show improvement in condition.

The highest mean $\mathrm{MCH}-\mathrm{C}$ after 14 days of treatment period was found in the positive control group at $34.867 \pm 0.383 \mathrm{~g} / \mathrm{dL}$, followed by the low dose squid ink treatment group at $34.6 \pm 0.629$ $\mathrm{g} / \mathrm{dL}$ and the low dose squid ink treatment group at $34.517 \pm 0.293 \mathrm{~g} / \mathrm{dL}$. The lowest mean $\mathrm{MCH}-\mathrm{C}$ was found in negative control group at $33.167 \pm 3.469 \mathrm{~g} / \mathrm{dL}$. Several pattern indicated gain from the condition observed prior

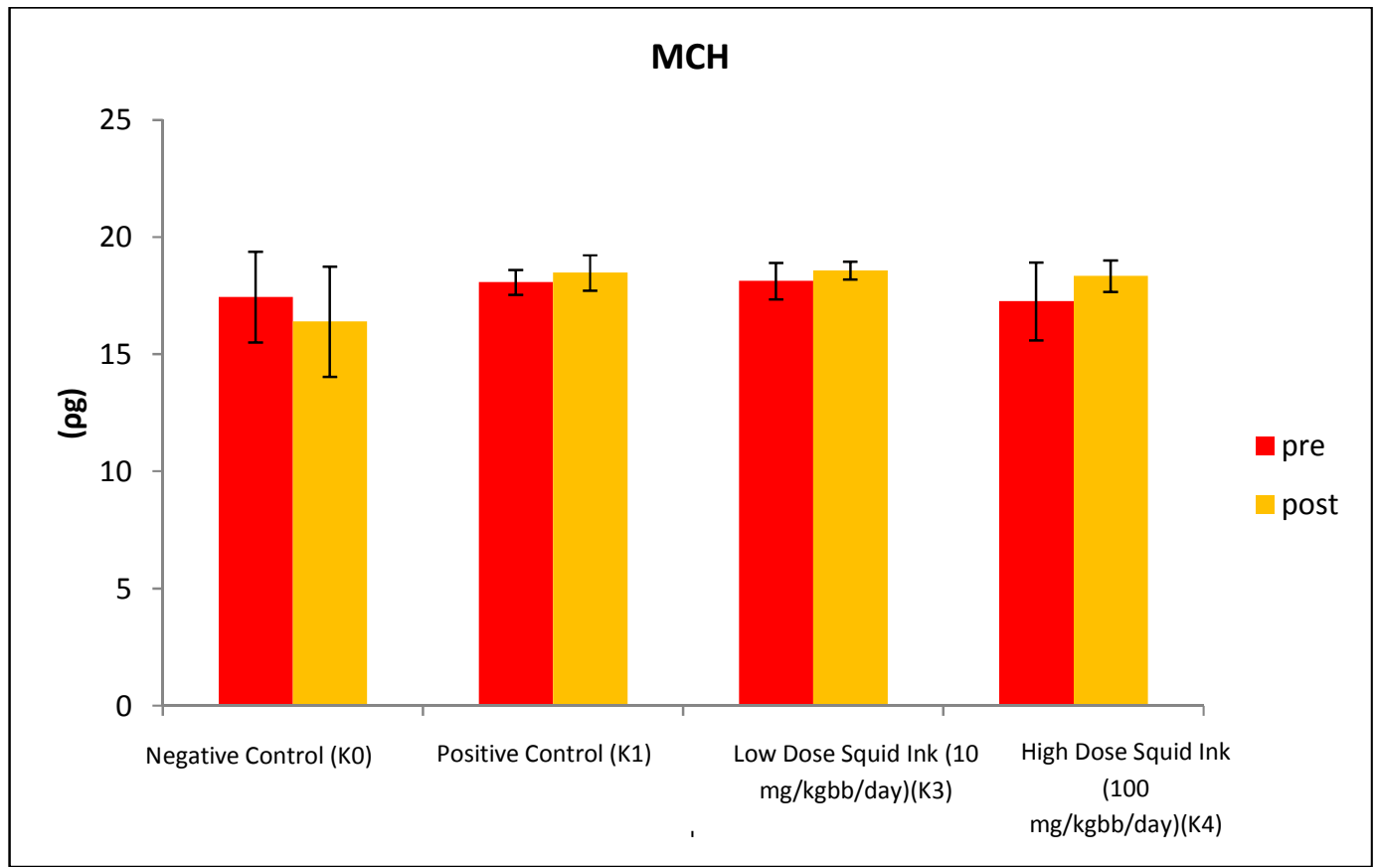

Fig. 6. $\mathrm{MCH}$ pattern diagram before and after treatment

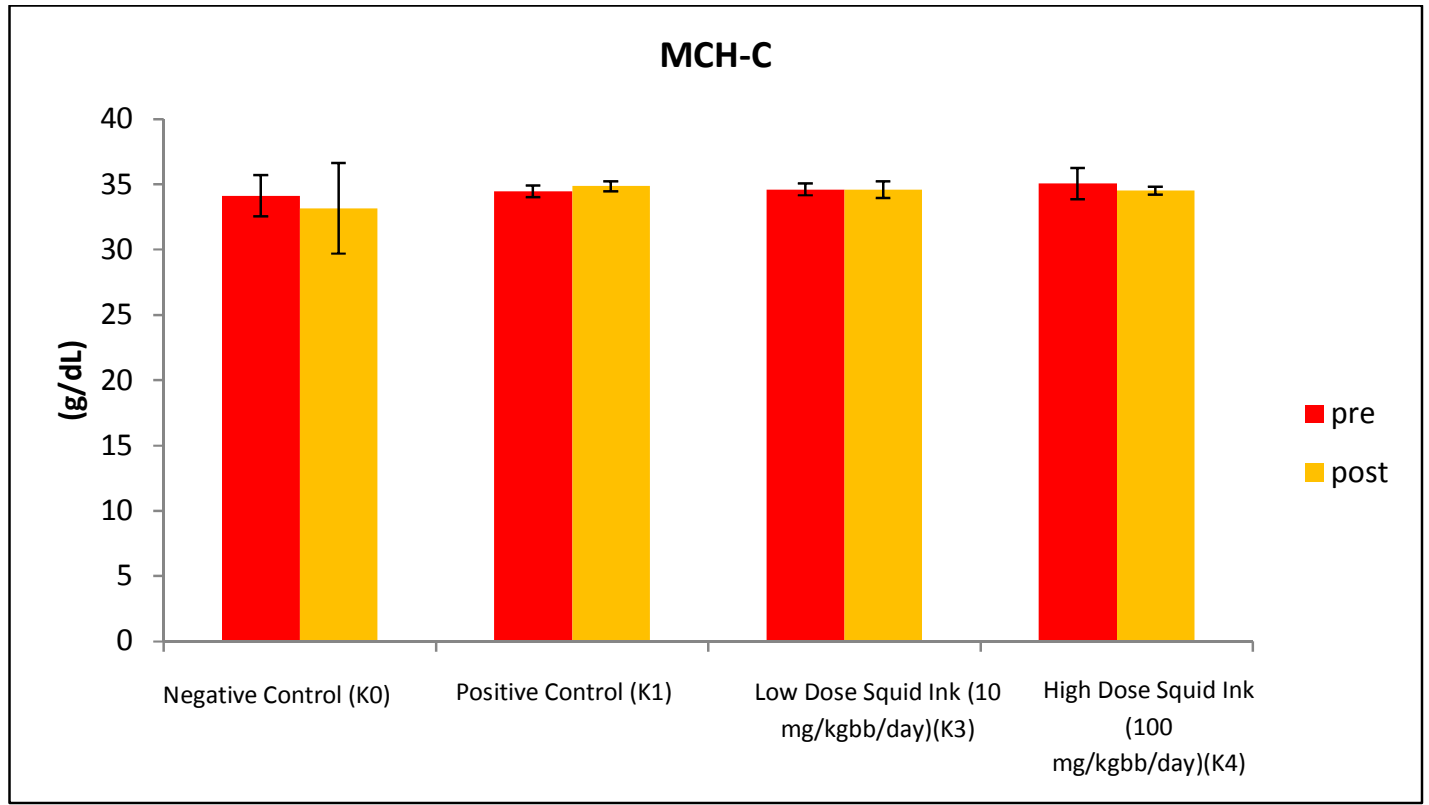

Fig. 7. $\mathrm{MCH}-\mathrm{C}$ pattern diagram before and after treatment 


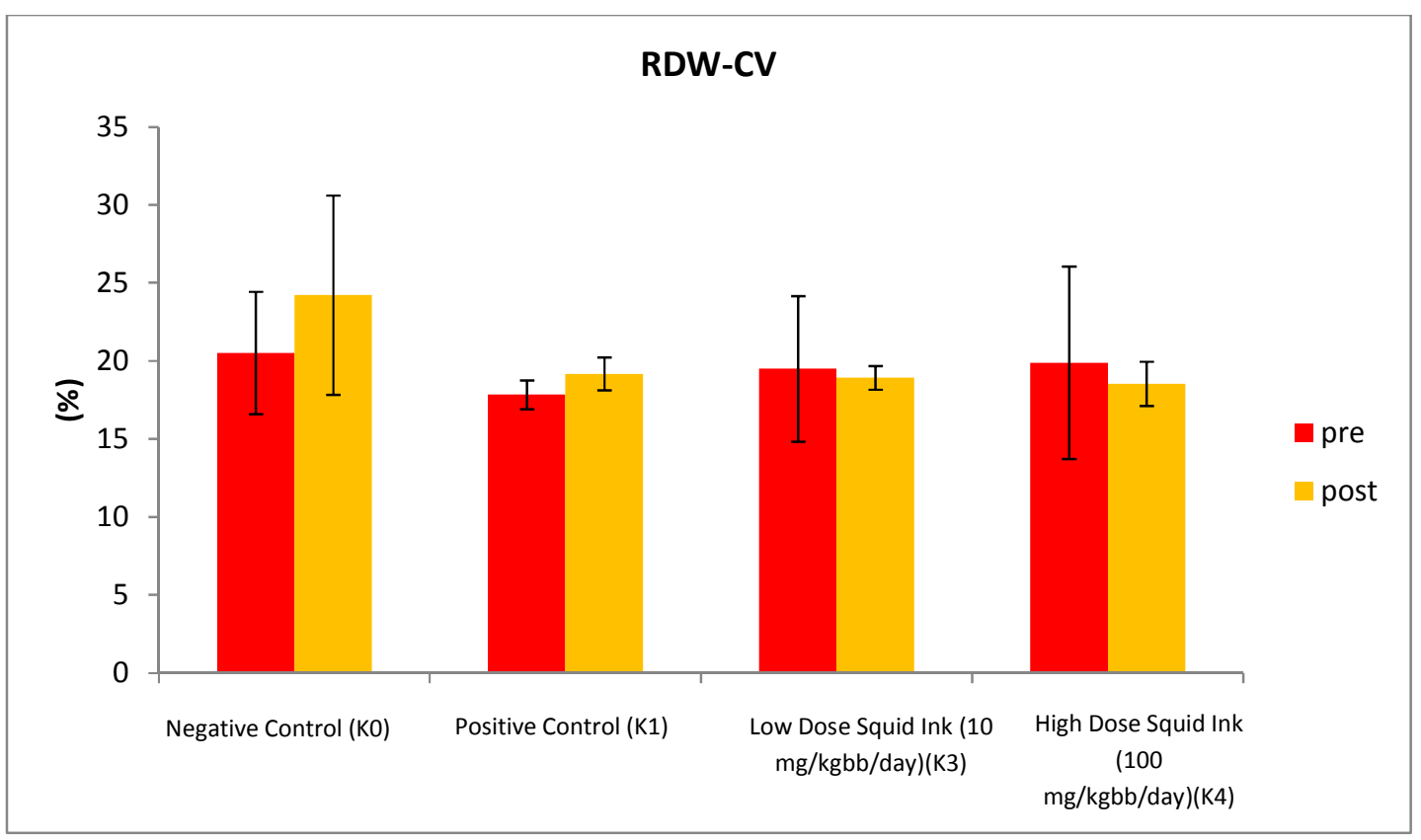

Fig. 8. Mean RDW-C pattern diagram before and after treatment

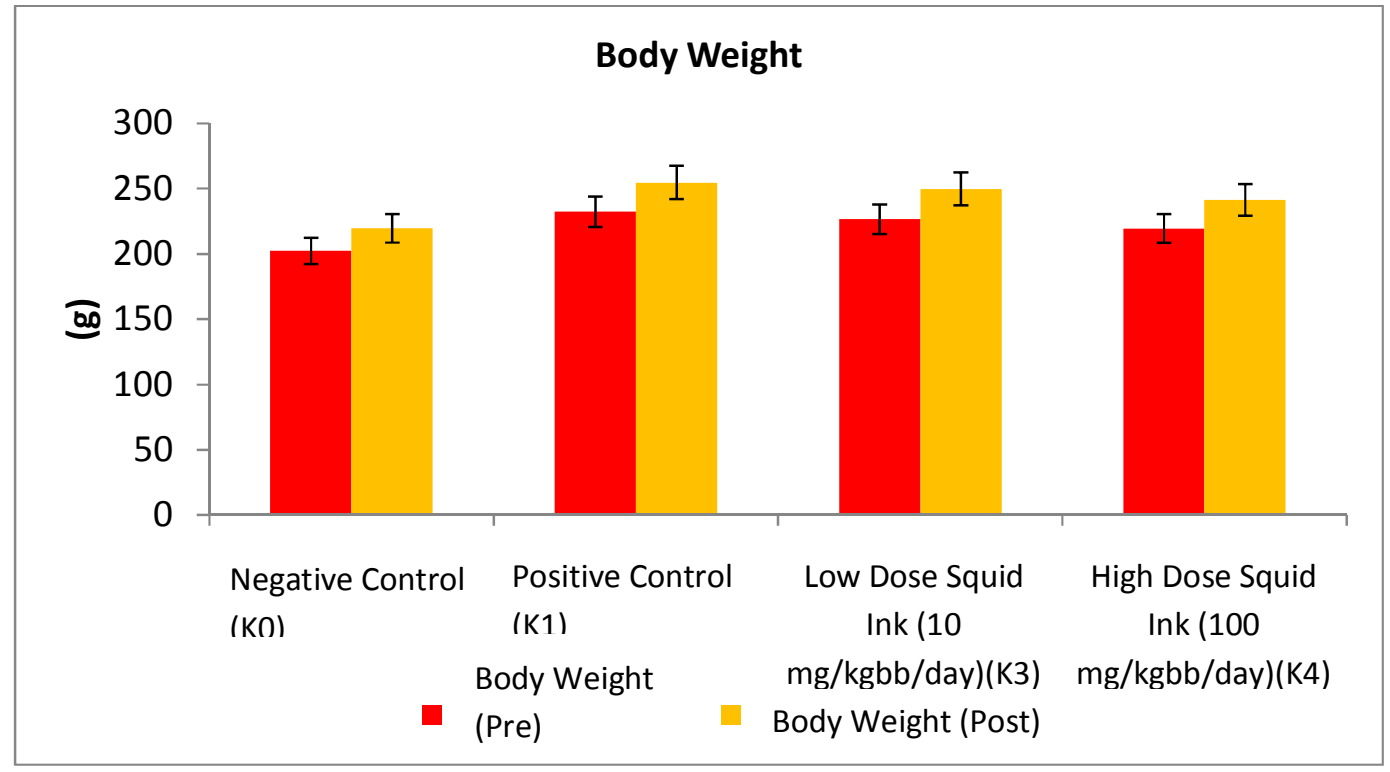

Fig. 9. Mean body weight pattern diagram before and after treatment

to the treatment, albeit very slightly, except for the values observed in subjects from negative control group and high dose squid ink treatment group.

The highest mean RDW-C after 14 days of treatment period was found in the negative control group at $18.583 \pm 0.387 \%$. This result was followed by positive control group at $18.483 \pm 0.755 \%$ and the low dose squid ink treatment group at $18.35 \pm 0.675 \%$. The lowest mean RDW-C was found in negative control group at $16.400 \pm 2.356 \%$. A pattern of condition improvement after intervention was observed among the treatment groups and positive control groups, albeit with almost negligible gain. The 
negative control did not show improvement in condition. Several pattern indicated gain from the condition observed prior to the treatment, albeit very slightly, except for the values observed in subjects from low dose squid ink treatment group, and with high dose squid ink treatment group actually showed loss.

Fig. 9 indicated that the highest body weight gain was found in low dose squid ink treatment group at 23.33 grams. The second highest bodyweight gain was observed in the positive control group, at a mean gain of 22,33 grams, or only 1 gram short of the highest gain. These results were followed by weight gain in high dose squid ink treatment group at 21.83 grams and in the negative control group at 17.33 grams. All subjects generally gained more than 15 grams of bodyweight after the intervention.

This bodyweight gain in all the subjects was not considered to be significant. There was no specific, body weight-based grouping of the subjects during this study, although the lowest mean bodyweight increase was found in negative control group. The body weight of the subjects at the time of the study indicated an insignificant correlation with $\mathrm{Hb}$ value $(\mathrm{p}>0.05)$, with the more significant correlation with bodyweight increase found in nutritional intake. High body weight is commonly attributed to high fat. However, a study found a significantly negative correlation between $\mathrm{Hb}$ count and Body Mass Index (BMI) along with body fat percentage. The gain in body fat is considered to be an indicator for low $\mathrm{Hb}$ count [8]. The previous study did not find any significant difference in the concentration of hemoglobin, MCV, serum iron, TIBC, transferrin saturation index, and ferritin among individuals with normal, overweight and obese individuals [9].

Table 1, presents further data on the results presented in the diagrams above.

Erythrocyte index count is included in hematological test, which consists of haemoglobin concentration count (MCH-C), RBC, Hematocrit (Hct), Mean corpuscular volume (MCV), Mean haemoglobin content

Table 1. Complete blood count test results, pre-intervention

\begin{tabular}{|c|c|c|c|c|c|c|c|}
\hline Group & $\begin{array}{l}\mathrm{Hb} \\
(\mathrm{g} / \mathrm{dL})\end{array}$ & $\begin{array}{l}\text { HCT } \\
(\%)\end{array}$ & $\begin{array}{l}\text { RBC } \\
\left(10^{6} / \mu \mathrm{l}\right)\end{array}$ & $\begin{array}{l}\text { MCV } \\
\text { (fL) }\end{array}$ & $\begin{array}{l}\text { MCH } \\
\text { (pg) }\end{array}$ & $\begin{array}{l}\text { MCHC } \\
\text { (g/dL) }\end{array}$ & $\begin{array}{l}\text { RDW- } \\
\text { CV (\%) }\end{array}$ \\
\hline $\begin{array}{l}\text { Negative Control } \\
\text { (K0) }\end{array}$ & $\begin{array}{l}13.367 \pm \\
1.587\end{array}$ & $\begin{array}{l}39.167 \pm \\
4.273\end{array}$ & & $\begin{array}{l}51.35 \pm \\
7.087\end{array}$ & $\begin{array}{l}17.45 \pm \\
1.941\end{array}$ & $\begin{array}{l}34.133 \pm \\
1.577\end{array}$ & $\begin{array}{l}20.512 \pm \\
3.922\end{array}$ \\
\hline Positive Control (K1) & $\begin{array}{l}14.383 \pm \\
0.854\end{array}$ & $\begin{array}{l}41.783 \pm \\
2.123\end{array}$ & & & $\begin{array}{l}18.083 \pm \\
0.534\end{array}$ & $\begin{array}{l}34.467 \pm \\
0.45\end{array}$ & $\begin{array}{l}17.833 \pm \\
0.93\end{array}$ \\
\hline $\begin{array}{l}\text { Squid Ink Treatment, } \\
\text { Low Dose (10 } \\
\text { mg/kgbw/day) (K2) }\end{array}$ & $\begin{array}{l}14.75 \pm \\
0.756\end{array}$ & $\begin{array}{l}42.612 \pm \\
2.038\end{array}$ & $\begin{array}{l}8.135 \pm \\
0.134\end{array}$ & $\begin{array}{l}52.367 \pm \\
2.086\end{array}$ & $\begin{array}{l}18.133 \pm \\
0.779\end{array}$ & $\begin{array}{l}34.612 \pm \\
0.449\end{array}$ & $\begin{array}{l}19.5 \pm \\
4,667\end{array}$ \\
\hline $\begin{array}{l}\text { Squid Ink Treatment, } \\
\text { High Dose (100 } \\
\text { mg/kgbw/day) (K3) }\end{array}$ & $\begin{array}{l}14.25 \pm \\
1.157\end{array}$ & $\begin{array}{l}40.75 \pm \\
4,154\end{array}$ & $\begin{array}{l}8.282 \pm \\
0.357\end{array}$ & $\begin{array}{l}49.433 \pm \\
5.947\end{array}$ & $\begin{array}{l}17.267 \pm \\
1.657\end{array}$ & $\begin{array}{l}35.067 \pm \\
1.2\end{array}$ & $\begin{array}{l}19.883 \pm \\
6.171\end{array}$ \\
\hline
\end{tabular}

Table 2. Complete blood count test results, post-intervention

\begin{tabular}{|c|c|c|c|c|c|c|c|}
\hline Group & $\begin{array}{l}\text { Hb } \\
{ }^{*}(g / d L)\end{array}$ & $\begin{array}{l}\text { HCT } \\
(\%)\end{array}$ & $\begin{array}{l}\text { RBC } \\
\left(10^{6} / \mu \mathrm{l}\right)\end{array}$ & $\begin{array}{l}\text { MCV } \\
\text { (fL) }\end{array}$ & $\mathrm{MCH}(\rho g)$ & $\begin{array}{l}\text { MCHC } \\
\text { (g/dL) }\end{array}$ & $\begin{array}{l}\text { RDW- } \\
\text { CV (\%) }\end{array}$ \\
\hline $\begin{array}{l}\text { Negative Control } \\
\text { (K0) }\end{array}$ & $\begin{array}{l}13.367 \pm \\
1.587\end{array}$ & $\begin{array}{l}37.933 \pm \\
7.053\end{array}$ & $\begin{array}{l}7.607 \pm \\
0.616\end{array}$ & $\begin{array}{l}50.383 \pm \\
11.62\end{array}$ & $\begin{array}{l}16.400 \pm \\
2.356\end{array}$ & $\begin{array}{l}33.167 \pm \\
3.469\end{array}$ & $\begin{array}{l}24.217 \pm \\
6.390\end{array}$ \\
\hline Positive Control (K1) & $\begin{array}{l}14.383 \pm \\
0.854^{\mathrm{a}}\end{array}$ & $\begin{array}{l}42.55 \pm \\
1.555\end{array}$ & $\begin{array}{l}8.028 \pm \\
0.342\end{array}$ & $\begin{array}{l}53.05 \pm \\
2.381\end{array}$ & $\begin{array}{l}18.483 \pm \\
0.755\end{array}$ & $\begin{array}{l}34.867 \pm \\
0.383\end{array}$ & $\begin{array}{l}19.183 \pm \\
1.050\end{array}$ \\
\hline $\begin{array}{l}\text { Squid Ink Treatment, } \\
\text { Low Dose (10 } \\
\text { mg/kgbw/day) (K2) }\end{array}$ & $\begin{array}{l}14.75 \pm \\
0.756^{\mathrm{a}}\end{array}$ & $\begin{array}{l}43.8 \pm \\
1,202\end{array}$ & $\begin{array}{l}8.158 \pm \\
0.362\end{array}$ & $\begin{array}{l}53.733 \pm \\
1.758\end{array}$ & $\begin{array}{l}18,583 \pm \\
0,387\end{array}$ & $\begin{array}{l}34.6 \pm \\
0,629\end{array}$ & $\begin{array}{l}18.917 \pm \\
0.752\end{array}$ \\
\hline $\begin{array}{l}\text { Squid Ink Treatment, } \\
\text { High Dose (100 } \\
\text { mg/kgbw/day) (K3) }\end{array}$ & $\begin{array}{l}14.25 \pm \\
1.157\end{array}$ & $\begin{array}{l}41.317 \pm \\
3.312\end{array}$ & $\begin{array}{l}7.782 \pm \\
0.757\end{array}$ & $\begin{array}{l}53.2 \pm \\
2,231\end{array}$ & $\begin{array}{l}18.35 \pm \\
0,675\end{array}$ & $\begin{array}{l}34.517 \pm \\
0.293\end{array}$ & $\begin{array}{l}18.533 \pm \\
1.422\end{array}$ \\
\hline
\end{tabular}


(MCH), Mean corpuscular hemoglobin concentration (MCHC) and Red blood cell distribution width (RDW). These tests provide the base for clarification for anemia, and they are used in several combinations to distinguish between iron deficiency and thalassemia [10].

$\mathrm{NaNO}_{2}$ can induce anemia due to its ability to bind $\mathrm{Hb}$ (by nitric reaction with oxyhemoglobin), turning haemoglobin into methemoglobin, which in turn increases oxygen and erythropoiesis [11]. Therefore, the introduction $\mathrm{NaNO}_{2}$ allows the decrease in haematological profile of the subjects such as $\mathrm{Hb}$ count. The effect went further to affect several erythrocyte index parameters such as Hct, MCV, MCHC, $\mathrm{MCH}$, RDW and RBC. The induction of $\mathrm{NaNO}_{2}$ produced consistent results across all the subjects since the dose was adjusted to be proportional to the bodyweight of the recipients. All subjects were also given the same diet to ensure the validity of the experiment. The foodstuff given to the subjects was low in iron contents.

The post-intervention observation indicated that there were different results in the negative control group (without any treatment postinduction of $\mathrm{NaNO}_{2}$ ) and treatment groups (K1, $\mathrm{K} 2$, K3), both using squid ink extract and Sangobion ${ }^{\circledR}$. The most significant differences were found in $\mathrm{Hb}$ indicator since it was the most immediate target after induction. This result indicated that the administration treatment, both using squid ink and iron supplement, impacted the haematological profile of subjects, particularly the treatment using low dose squid ink. However, it was also found that there was no significant difference in the results from treatments with Sangobion ${ }^{\circledR}$ and low dose squid ink did. Thus it was concluded that treatment with Sangobion ${ }^{\circledR}$ and low dose squid ink did produce similar results.

One of the indicators of the nutritional balance of the subjects in this research were the correlation between RDW and MCV. RDW is a mathematical count which describes the number of anisocytosis (cellular size variation) and in certain stages may indicate poikilocytosis (abnormal shape and size) of red blood cells on fringe blood test. RDW reflects the variation coefficient of red blood cell volume distribution. Both MCV and RDW are determined from the results of erythrocyte histogram (RBC) $[12,13]$.

This study found that the negative control group had high RDW-CV and low MCV, which indicated that this control group suffered from iron deficiency. High RDW and low MCV value can be interpreted as a condition of iron deficiency or Sickle $\beta$-thalassemia, whereas high RDW with normal MCV value can indicate early iron deficiency, early b12 deficiency, early folate deficiency, sickle cell anemia, sc disease, chronic liver disease, and myelodysplasia [14]. Positive control group (K1), low dose squid ink treatment group (K2) and high dose squid ink treatment group (K3) indicated high RDW with normal MCV values. Therefore, K1, K2 and K3 were all in good condition, on an 'early iron deficiency' note.

Before and after intervention in this study, the negative control group showed a decreasing trend of measured values such as $\mathrm{Hb}, \mathrm{RBC}$, Hct, $\mathrm{MCV}, \mathrm{MCH}, \mathrm{MCHC}$ and an increase in RDW. The opposite phenomenon was found in positive control and treatment groups, which showed trend of stable or increasing erythrocyte index value. Generally, the cause of high RDW value is attributed to iron, vitamin B12 or folic acid deficiency, making normal-sized erythrocyte mixed with smaller or bigger-sized ones (Hammarsten et al. 2010).

RDW gain was also observed in the positive control group, which was given supplement rich in iron and vitamin B12. This supplement increase or maintain erythrocyte index value after the induction of $\mathrm{NaNO}_{2}$. This result confirms the findings in Hammarsten et al. (2010) in which RDW gain was also observed after administration of supplements rich in iron, vitamin B12 and folate during the proliferation of reticulocyte. RDW value also generally increase post blood transfusion, as found in individuals with hemolytic and thrombotic anemia, where the erythrocyte gets fragmented within circulation.

Squid ink treatment groups also showed significant difference in pre and post-intervention. The iron contents of the squid ink was attributed to the improvement since its optimum absorption was enabled by the use of acetic acid during the preparatory process. However, it is also possible that ink from other squid species may produce similar or better results compared to that which was determined in this study. Other compounds that may produce better results are squid ink with melanin containing tyrosine [15]. This tyrosine content is believed to be able to maintain and, over time, recover $\mathrm{Hb}$. The formation of $\mathrm{MetHb}$ by the induction of $\mathrm{NaNO}_{2}$ is due to its reaction with ROS (reactive oxygen species) such as 
hydrogen peroxide $\mathrm{H}_{2} \mathrm{O}_{2}$ which took place during the auto oxidation of $\mathrm{OxyHb}$ in $\mathrm{Hb}$ vesicle, which may cause the deterioration of $\mathrm{O}_{2}$ gaining capability. A mixture of MetHb and L-Tyrosine can effectively eliminate the capability of $\mathrm{H}_{2} \mathrm{O}_{2}$ by utilizing reverse peroxidase activity in MetHb, with L-Tyrosinase as its donor. This process will gradually turn MetHb into $\mathrm{Hb}$ [16]. Residue of Tyrosine can act as a redox center which facilitate iron oxidation mitigation which is higher than $\mathrm{Hb}$, and this process is often found in nature by reducing oxidative reactivity $[17,18]$. This finding is in line with the results of a study by Lei et al. [19] which stated that squid ink enhances the internal environment of the subcjets through free-radical scavenging of oxygen and by being antioxidant in nature, protecting erythrocyte from hemolysis and improving the therapy for iron deficiency anemia. However, inorganic iron in commercial food supplements do not seem to give this effect.

The statistical analysis of $\mathrm{K} 2$ and $\mathrm{K} 3$ showed that the differences in the dose administered had no significant correlation on the level of measured $\mathrm{Hb}$, since $p>0.05$. It was found that the lower dose of squid ink treatment had better $\mathrm{Hb}$ value. Further study is required to determine the exact cause of this phenomenon. Although there was no issue on the absorption of iron in the ink, the authors suspected that this was caused by intoxication from extremely high dose of squid ink in $\mathrm{K} 3$, exactly 10 times of that which was administered to K2 or exceeding $96 \mathrm{ppm}$. One study by Pringgenies et al. [20] also found that at $95.951 \mathrm{ppm}, 100 \%$ of Artemia salina population was exterminated. This indication was also reflected by the $\mathrm{MCHC}$ and $\mathrm{RBC}$ count, which was measured lower on pre-treatment of high dose squid ink (see RBC diagram). Another suspected cause of this phenomenon was that the content of hepcidin in $\mathrm{K} 3$ subjects might be lower than that of K2 subjects, or it might be that the iron reserve (in the form of ferritin or hemosiderin) in K2 subjects was higher than that of $\mathrm{K} 3$ subjects. However, these postulation were merely educated guess since the cause was not exactly studied during the experiment. This result was particularly apparent during serum iron (SI), free erythrocyte protoporphyrin (FEP), total iron binding capacity (TIBC) and unsaturated iron binding capacity (UIBC) tests.

\section{CONCLUSION}

The research found that the ink of Sepioteuthis lessoniana squid contained $2.14 \pm 0.46 \mathrm{mg} / \mathrm{g}$ of iron. After 14 days of treatment, data analyses indicated that the squid ink affected the haematological profile of the subjects, particularly on the erythrocyte index value of haemoglobin, red blood cell count (RBC), hematocrit (Hct), mean cell volume (MCV), mean cell haemoglobin $(\mathrm{MCH})$, mean cell haemoglobin concentration (MCHC) and red cell distribution width (RDW) without observable body weight loss on the subjects of treatment and positive control groups. The subjects of negative control groups showed loss in all values but RDW. The statistical analysis of data showed that the administration of low dose squid ink and positive control indicated significantly positive correlation $(p<0.05)$ compared to the negative control group.

The most significant correlation was found on the $\mathrm{Hb}$ count between the treatment group of low dose squid ink and positive control group compared to the negative control group $(p<0.05)$.

\section{ETHICAL APPROVAL}

As per international standard or university standard ethical approval has been collected and preserved by the authors.

\section{ACKNOWLEDGEMENTS}

The authors would like extend their most sincere gratitude to the Dean of The Faculty of Fisheries and Marine Science, Diponegoro University, Semarang and the Dean of School of Medicine, Diponegoro University, Semarang who both have kindly given the opportunity for the authors to conduct research in their respective laboratories and which enabled desirable result from this research.

\section{COMPETING INTERESTS}

Authors have declared that no competing interests exist.

\section{REFERENCES}

1. Lopez A, Patrice C, Macdougall IC, PeyrinBiroulet L. Iron Deficiency Anaemia. 2016; 1-10. DOI: 10.1016/S0140-6736(15)60865-0

2. Wang FR, Xie ZG, Ye XQ, Deng SG, Hu $Y Q$, Guo $X$, Chen SG. Effectiveness of treatment of iron deficiency anemia in rats with squid ink melanin-Fe. Food Funct. 2014;5(1):123-8.

DOI: $10.1039 / \mathrm{c} 3 f \circ 60383 \mathrm{k}$ 
3. Bianchi VE. Role of nutrition on anemia In elderly. Journal of Clinical Nutrition. 2016;1-11. ESPEN xxx; 2015.

DOI: 10.1016/j.clnesp.2015.09.003

4. Souza Al, Filho MB, Bresani CC, Ferreira LOC, Figueiroa JN. Adherence and side effects of three ferrous sulfate treatment regimens on anemic pregnant women in clinical trials, Cad. Saude Publica. 2009; 25:1225-1233.

5. Agustini TW, Hadiyanto Wijayanti I, Amalia $U$, Benjakul S. Effect of melanin free ink extracted from squid (Loligo sp.) on proximate and sensory characteristics of soft-bone milkfish (Chanos chanos) During Storage. IOP Conf. Ser.: Earth Environ. Sci. 2018;116:012031.

DOI: 10.1088/1755-1315/116/1/012031

6. Gluhchevaa Y, Ivanovb I, Petrovaa E, Pavlovaa E, Vladova I. Sodium nitriteinduced hematological and hemorheological changes in rats. Series On Biomechanics. 2012;27(3-4):53-58.

7. Rahmawati $\mathrm{N}$, Iwan $\mathrm{H}$, dan Yusi $\mathrm{D}$. Ekstraksi zat besi dalam daun singkong sengan pelarut cukaaren menggunakan armfield uop4 solid-liquid extraction unit. prosiding seminar nasional sains dan teknologi nuklir PTNBR - Batan, Bandung; 2013.

8. Acharya $S$, Minati $P$, Snigdha PM, Amita $\mathrm{KP}$. Correlation of hemoglobin versus body mass index and body fat in young adult female medical students. National Journal of Physiology, Pharmacy and Pharmacology. 2018;8(10):1371-1373. DOI:10.5455/njppp.2018.8.061991206201 8

9. Anari AG, Nazemian N, Ardakani HAV. Association of body mass index with hemoglobin concentration and iron parameters in iranian population. ISRN Hematol. 2014;2014:525312.

DOI: $10.1155 / 2014 / 525312$

10. Briggs C. Bain BJ. Basic haematological techniques. Chapter 3 of Practical Hematology Book. 2017;18-49.

11. Keszler A, Piknova B, Schechter AN, Hogg $\mathrm{N}$. The reaction between nitrite and oxyhemoglobin a mechanistic study. The Journal of Biological Chemistry. 2008;283(15):9615-9622.

DOI: 10.1074/jbc.M705630200

12. Constantino BT. The red cell histogram and the dimorphic red cell population. Labmedicine. 2011;42:300-308.

13. Turgeon ML. Clinical Hematology Theory and Procedures. Fifth edition. Philadelphia: Lippincott Williams \& Wilkins, a Wolters Kluwer Business. 2005;103-104, 543-544.

14. Marks PW. Anemia: clinical approach. In Lazarus HM, Schmaier AH. Concise guide to hamatology. Oxford: Wiley-blackwell; 2012.

15. Derby C. Cephalopod ink: Production, Chemistry, function and application. Marine Drugs. 2014;12:2700-2730.

DOI: 10.3390/md12052700

16. Atoji T, Aihara M, Sakai H, Tsuchida E, Takeoka S. Hemoglobin vesicles containing methemoglobin and L-tyrosine to suppress methemoglobin formation in vitro and in vivo. Bioconjug Chem. 2006;17 (5):1241-1245.

17. Reeder BJ, Cutruzzola F, Bigotti MG, Hider RC, Wilson MT. tyrosine as a redoxactive center in electron transfer to ferryl heme in globins free radic. Biol. Med. 2008;44(3):274-283.

18. Silkstone GG, Silkstone RS, Wilson MT, Simons M, Bulow L, Kallberg K, Ratanasopa K, Ronda L, Mozzarelli A, Reeder BJ, Cooper CE. Engineering tyrosine electron transfer pathways decreases oxidative toxicity in hemoglobin: implications for blood substitute design. Biochem. J. 2016;473(19):3371-3383.

19. Lei M, Xue CH, Wang YM, Li ZJ, Xue Y, Wang JF. Effect of squid ink melanin-fe on iron deficiency anemia remission. Journal of Food Science. 2008;73(8):207-h211.

20. Pringgenies D, Sasongko AS, Sedjati S. Karakterisasi tinta cumi-cumi (Sepiotheuthis lessoniana) dan toksisitasnya. Pertemuan IImiah Nasional Tahunan X ISOI. 2013;244-253.

(c) 2020 Pringgenies et al.; This is an Open Access article distributed under the terms of the Creative Commons Attribution License (http://creativecommons.org/licenses/by/4.0), which permits unrestricted use, distribution, and reproduction in any medium, provided the original work is properly cited.

\section{Peer-review history:}

The peer review history for this paper can be accessed here: http://www.sdiarticle4.com/review-history/55320 